\title{
MUSLIM WOMEN'S POLITICS IN ADVANCING THEIR GENDER INTERESTS: \\ A Case-Study of Nasyiatul Aisyiyah in Indonesian New Order Era
}

\section{Siti Syamsiyatun}

Faculty of Dakwah, Sunan Kalijaga State Islamic University Yogyakarta, Indonesia

\section{Abstract}

This article analyses a strategy of Nasyiatul Aisyiyah, a youth Muslim women organization, in developing its ideology and the importance of gender in the reign of New Order Indonesia (1966-1998). In the name of political stability, the New Order applied a tight political control towards mass-religious based organizations and tried to minimize their militancy by forming new women's movement organizations such as Dharma Wanita and PKK that are easily controlled by the government. As an Islamic women organization, Nasyiatul Aisyiyah underwent the surveillance practiced by the government via those two bodies; however Nasyiatul Aisyiyah could constantly maintain its entity as an Islamic women organization. In the 1980s when the New Order Regime was predominantly in power, Nasyiatul Aisyiyah held negotiations and adapted to the governmental gender policy to assure the position and the interests of young women.

Keywords: Women Organization, Gender, Interest, Nasyiatul Aisyiyah, Politics, New Order.

\section{A. Introduction}

In this paper, I am adapting Deniz Kandiyoti's assertion that it is not sufficient to examine women's issues in Muslim societies by 
focusing solely on what the official Islamic texts have said about to women's issues. ${ }^{1}$ The application of discriminatory treatment against women by state governments has been a neglected area in the Muslim world almost in the same way that women's historical realities have been given inadequate attention in the study of religion. In the Indonesian context, there have been many studies which show how religion and Islamic organizations have played major roles in national political processes since independence. ${ }^{2}$

While there has been a notable growing interest in studying various aspects of Indonesian women's lives and their organizations, very little research has been done specifically linking a women's group with religion and politics. Jamhari and Ismatu Ropi in their edited book explore the views of several Muslim's women's organizations, notably Aisyiyah, Muslimat NU, Persistri, and Al-Irsyad Women, on the status of women in Islam with regard to decision making and leadership. ${ }^{3}$ From their study it is obvious that Muslim women have diverse views regarding the issues being elaborated, thus confirming the allegation

1 Deniz Kandiyoti, ed., "Introduction" in Women, Islam and the State (London: Macmillan, 1991), pp. 1-2.

2 The following studies on religion and politics in Indonesia are accessible to international readers: see Allan Samson, "Army and Islam in Indonesia" in Pacific Affairs XLIX No. 4 (Winter 1971-1972); "Indonesian Islam since the New Order" in Readings on Islam in Southeast Asia, edited by A. Ibrahim, S. Siddique and Y. Husain (Singapore: Institute of Souetheast Asian Studies, 1985); Andree Feillard, "Traditionalist Islam and the Army in Indonesia's New Order: the Awkward Relationship" in Nabdlatul Ulama, Traditional Islam and Modernity, edited by G. Barton and G. Fealy (Clayton, VIC: Monash Asia Institute, 1996); Douglas Ramage, Politics in Indonesia: Democracy, Islam and the Ideology of Tolerance (London and New York: Routledge 1995); Greg Barton, "Islam and Politics in the New Indonesia" in Islam in Asia: Changing Political Realities, edited by J.F. Isaacson and C. Rubenstein (New Brunswick: Transaction Publishers, 2002); Marcus Mietzner, "Nationalism and Islamic Politics: Political Islam in the post-Soeharto Era" in Reformasi: Crisis and Changes in Indonesia, edited by A. Budiman, B. Hartley, D. Kingsbury (Clayton, VIC: Monash Asia Institute, 1999), Dien M. Syamsuddin, "Religion and Politics in Islam: the Case of Muhammadiyah in Indonesia's New Order", dissertation submitted to the University of California Los Angeles, 1991; Muhammad Kamal Hassan, Muslim Ontellectual Responses to New Order Modern ization in Indonesia (Kuala Lumpur: Dewan Bahasa dan Pustaka Kementrian Pelajar Malaysia, 1982).

3 Jamhari and Ismatu Ropi et al., Citra Perempuan dalam Islam: Pandangan Ormas Keagamaan (Jakarta: Gramedia Pustaka Utama, 2003). 
that women, in this case Indonesian Muslim women, are not a homogeneous entity. Similar diversity is found among Christian women in Indonesia. Frances Adeney's research shows how Christianity has left influences differently to diverse groups of women in many parts of Indonesia, such as Java, Minahasa, Maluku, Nusa Tenggara and Papua. ${ }^{4}$ While both works by Jamhari-Ropi and Adeney do link religion and gender, they do not intentionally relate their study to politics, or show how women responded to political agenda of the State within the framework of religious discourse. The present paper attempts to examine how a particular Muslim women's organization, Nasyiatul Aisyiyah (henceforth shortened as Nasyiah), responded to the New Order Regime's policies regarding women's issues. Nasyiah is a socialreligious (Islam) organization for the betterment of young women's status, conditions and roles in society. It is also an autonomous organization of Muhammadiyah, one of the largest and most influential Muslim organizations in Indonesia. The paper aims to answer the following questions: in what ways and to what extent did Nasyiah's program accord with the government agenda on Indonesian womanhood, and what strategies were implemented by the women of Nasyiah to improve the life conditions of young women?

The data for this study was collected through a fieldwork undertaken from June to October 2003, and will be analysed by using a qualitative approach. In the first section, I will outline the framework within which Muslims have interpreted the most basic religious texts, the Qur'ann and badith (the sayings, deeds and agreements of the Prophet Muhammad), followed by a brief presentation of some major policies regarding women's issues implemented by the New Order government of Indonesia (1966-1998). In the third section I will provide a brief presentation of Nasyiah as a young Muslim women's organization. The fourth section highlights the ways in which Nasyiah women have developed a religious discourse to break the state's dominance in dealing with women issues. It will be argued that Indonesian Muslim women, however painful and difficult the process might be under undemocratic

${ }^{4}$ Frances S. Adeney, Christian Women in Indonesia: A Narrative Study of Gender and Religion (New York: Syracuse, 2003). 
government, had to adopt specific strategies and take certain actions to deal with the politics of the State. The women of Nasyiah have consistently made creative use of 'consultation' with Qur'anic text and made references to it in addressing women's issues. They also developed their own ways of empowering young women which are different from those applied by other contemporary women's NGOs.

\section{B. In Search of Authentic Islamic View on Womanhood}

Most Muslims, including women of Nasyiah, maintain a strong belief that Islam should be the principal source of ethics for them, regardless of whether or not it is adopted as the official religion of the state. In its constitution, Nasyiah declares its identity as an Islamic organization for young Muslim women as aiming at creating a virtuous Muslim community. ${ }^{5}$ Based on this claim, it is obvious that Islam is a major source of ethics and values of Nasyiah. Its mission should be seen within a framework of searching and implementing Islamic teaching in response to the gender politics of Indonesian New Order government. In this section I briefly outline some relevant methods applied by Muslims in making references to the Qur'an for their daily life.

Considering that there are very few Qur'anic verses explicitly outlining laws to regulate social lives, early Muslim thinkers applied ijtibàd (independent reasoning to conclude a practical law) to respond to the changing problems faced by their communities according to the needs of time and place. As a result, many diverse Islamic laws have been adopted by different Muslim societies. One particular school of thought might have dominated the whole discourse on Islamic laws in a certain area or period, while others became the mainstream elsewhere. Despite the issue of hegemonic tendency, one of the most debated problems in this ijtibād process in all schools (madhbab) has been the exclusion of women and the denial of their rights to access and engage in the process. Moreover, most popular scholars interpreting the Qur'an and developing Islamic law and knowledge have been male. Thus men's

5 Pimpinan Pusat Nasyiatul Aisyiyah, Anggaran Dasar dan Anggaran Rumab Tangga Nasyiatul Aisyiyah (Yogyakarta: PP Nasyiatul Aisyiyah, 2001). 
views and experiences of lives have been incorporated into the process of reading and understanding the Qur'anic messages, while women's point of view and their experiences have been excluded from the debate in the making of practical Islamic laws. ${ }^{6}$ It seems that the roles of the Prophet's wives and his female relatives in constructing Islamic knowledge and society in early days of Islam have been forgotten. ${ }^{7}$

Consequently, Islamic laws on women-related issues, such as women's rights in marriage, divorce, child custody, employment, education, dress code, and political participation implemented in several Muslim societies have become male-biased, as exemplified in Iran under the Khomeini regime, ${ }^{8}$ in Saudi Arabia, ${ }^{9}$ and other Muslim countries. ${ }^{10}$ However, such patriarchal ways of life are not exclusively practiced among Muslim societies; women living in other parts of the world or religious groups indeed have experienced similar discrimination because of their being women, color, political aspirations, etc. ${ }^{11}$

Among several works on Islam and the question of woman produced by contemporary Muslim thinkers, the books by Fazlur Rahman (1982) and Amina Wadud (1999) on interpreting the Qur'anic and prophetic teachings regarding women's issues are the most popular,

${ }^{6}$ Amina Wadud, Qur'an and Women: Rereading the Sacred Text from a Women's Perspectives (New York: Oxford University Press, 1999), p.2.

${ }^{7}$ Fatima Mernissi, Women and Islam: An Historical and Theological Enquiry. Translated by M. JoLakeland (Oxford: Basil Blackwell, 1991), pp. 115-125.

${ }^{8}$ Masoud Kazemzadeh, Islamic Fundamentalism, Feminism, and Gender Inequality in Iran under Khomeini (Lanham, Maryland: University Press of America, 2002).

9 Eleanor Abdella Doumato, "Education in Saudi Arabia: Gender, Jobs, and the Price of Religion" in Women and Globalization in the Arab Middle East: Gender, Economy and Society, edited by E.A. Doumato and M.P. Posusney (Boulder, Colorado: Lynne Rienner Publishers, 2003).

${ }^{10}$ Valentine M. Moghadam, Modernizing Women: Gender and Social Change in the Middle East (Boulder, Colorado: Lynne Rienner Publishers, 2003); Azza M. Karam, Women, Islamism and the State: Contemporary Feminism in Egypt (London: Macmillan Press Ltd, 1998).

${ }^{11}$ Kumari Jayawardena, Feminism and Nationalism in the Third World (London: Zed Books, 1986); Saskia Wieringa, Women's Struggles and Strategies (Aldershot EnglandBrookfield, USA: Gower, 1988). 
and are often consulted by young Indonesian Muslim women feminists. ${ }^{12}$ Unlike the literalists who insist on word to word implementation of the Qur'anic rules at all times and places, Rahman believes it is more important that the moral ideals contained in the Qur'an be cultivated and implemented rather than its apparent specific legal commands. Rahman argues that in many of its verses that reveal rules for social life, the Qur'an was responding to or giving solutions for particular and historical problems faced by the Prophet and his community in seventh century Arabia. ${ }^{13}$ Whilst giving such solutions or rulings, the Qur'an always provides the rationale, so that Muslims can figure out general moral and spiritual principles rather than assume and implement the verses literally.

In agreement with Rahman's proposal, Amina Wadud says that, while the Qur'an attempts to establish an all-inclusive foundation of moral guidance, its gendered Arabic text was restricted by the particular conditions of the specific time when it was revealed. She advocates using Rahman's methodology in interpreting the Qur'ann. ${ }^{14}$ In addition, she proposes employing a hermeneutic model, considering the fact that the Qur'an was revealed in Arabic, one of the gendered languages. She outlines the model as follows:

All verses which contained any reference to women, separately or together with men, were analysed with the traditional method of tafsir al-qur'an bi'l-qur'an (interpretation of the Qur'an based on the Qur'an itself). However, I elaborated these particular terms of this method: each verse was analysed: 1 . in its context; 2 . in the context of discussion on similar topics in the Qur'an; 3. in the light of similar language and syntactical structures used elsewhere in the Qur'an; 4. in the light of overriding Qur'anic principles; and 5. within the context of the Qur'anic Weltanschaunng, or world-view. ${ }^{15}$

${ }^{12}$ Fazlur Rahman, Islam and Modernity: Transformation of an Intellectual Tradition (Chicago and London: The University of Chicago Press); Amina Wadud, Rereading the Sacred Texts.

${ }^{13}$ Fazlur Rahman, Islam and Modernity, pp 5-7.

${ }^{14}$ Amina Wadud, Rereading the Sacred Texts, pp 3-4.

${ }^{15}$ Amina Wadud, Rereading the Sacred Texts, p. 5. 
Rahman and Wadud's proposals on interpreting Islamic texts on woman question by using hermeneutical approach have received wide attention from various segments of Muslim societies: from academic intellectuals to women's activists. A number of books dealing with Islam and women's issues have been produced by Indonesian scholars. ${ }^{16}$ The debate on women's status and rights in Muslim community is not a new phenomenon; however, it has become more heated in recent decades with the spread of feminism in the so-called Muslim countries. Different groups have been involved, ranging from political elites, defenders of nationalist causes, religious authorities to women activists and social workers. Women's behaviour has been projected as an important catalyst for genuine nationality and religiosity. Despite all the obstacles to its development, feminism has been perhaps one of the most contested and yet far-reaching movements in the twentieth century. Compared to other sciences developed in the West, feminism as an area of study has not been received easily in the so-called developing world and Muslim societies for many reasons. This is not meant to imply, however, that any feminist consciousness is absent in these communities.

Amongst the most popular explanations as to why feminism has been such a controversial discourse is that feminism is an alien, foreign concept imported from the West, which might introduce destructive or unsuitable elements to indigenous cultural, as well as religious, values and norms. ${ }^{17}$ Moreover, memories and experiences of being colonized

${ }^{16}$ The followings are among the most important works on Islam and women's issues written by Indonesian scholars: Hamim Ilyas et al, Perempuan Tertindas: Kajian Hadis 'Misoginis' (Yogyakarta: PSW UIN Sunan Kalijaga bekerjasma dengan the Ford Foundation, 2003); Yunahar Ilyas, Feminisme dalam Kajian Tafsir Qur'an Klasik dan Kontemporer (Yogyakarta: Pustaka Pelajar, 1997); Faqihuddin Abdul Kadir, ed. Fiqh Perempuan: Refleksi Kyai atas Wacana Agama dan Gender (Yogyakarta: Rahima, the Ford Foundation, LKiS, 2001); Siti Musdah Mulia, Pandangan Islam tentang Poligami (Jakarta: Lembaga Kajian Agama dan Jender, Solidaritas Perempuan dan the Asia Foundation, 1999); Nasaruddin Umar, Argumen Kesetaraan Gender: Perspektif Al-Qur'an (Jakarta: Paramadina, 1999); Kodrat Perempuan dalam Islam (Jakarta: Lembaga Kajian Agama dan Jender, 1999); Siti Ruhaini Dzuhayatin et al, Rekonstruksi Metodologis Wacana Kesetaraan Gender dalam Islam (Yogyakarta: PSW UIN Sunan Kalijaga, McGill-CIDA dan Pustaka Pelajar, 2002).

\footnotetext{
${ }^{17}$ Kumari Jayawardena, Feminism and Nationalism, p. 3.
} 
by the West have not faded from people's minds; rather they have become refreshed when relations between Western and Muslim countries have deteriorated in recent years since the $9 / 11$ 2001. Such fluctuating and ambivalent situations have had a clear impact on the development of feminism as an intellectual discourse in regions mostly populated by Muslims. Many religious authorities in Middle Eastern countries have even confirmed that engaging feminism could lead one to a betrayal to one's own culture and religion. ${ }^{18}$ As in India, ${ }^{19}$ the discourse of feminism among Indonesian Muslim communities was developed slowly through philanthropic associations, which then expanded to also advocate women's rights in the area of education, employment, and politics. The emergence of women's movement, which marked a growing awareness of feminism in the early 20th century, was initiated by political impetus for national identity and religious as well as cultural reform to modernizing society, as in other parts of the developing world. ${ }^{20}$ Since Indonesia gained its independence, the discourse of feminism has often been manipulated by the State. In fact, the State's control towards women has continued more than half a century after its independence, ${ }^{21}$ with an arguable exception during the 1950s, as argued by Elizabeth Martyn. ${ }^{22}$

It is in this framework of ambiguous attitudes of the state and religious authorities towards women's affairs that I put the discussion of Nasyiah's agenda and strategy to advance its members' interests

${ }^{18}$ Azza M. Karam, Women, Islamism and the State, pp. 191; 193; Masoud Kazemzadeh, Islamic Fundamentalism, Feminism, and Gender Inequality, p.17.

${ }^{19}$ Azra Asghar Ali, The Emergence of Feminism Among Indian Muslim Women 19201947 (Oxford: Oxford University Press, 2000).

${ }^{20}$ Kumari Jayawardena, Feminism and Nationalism, p. 3.

${ }^{21}$ Julia Suryakusuma, "State Ibuism: The Social Construction of Womanhood in the Indonesian New Order" in New Asian Vision 16 (1991) No 2; "The State and Sexuality in New Order Indonesia" in Fantasizing the Feminine in Indonesia, edited by L.J. Sears (Durham and London: Duke University Press, 1996); "Kultur Politik Kekerasan" in Politik Kekerasan ORBA: Akankah Terus Berlanjut, edited by S.A. Karim (Bandung: Mizan, 1999).

${ }^{22}$ Elizabeth Martyn, “Gender, Nation in a New Democracy: Indonesian Women's Organizations in the 1950s", Dissertation submitted to Monash University, Australia, 2001. 
and needs. The next sections will examine some of the New Order's policies on women's issues and how Indonesian women have responded to them.

\section{New Order Gender Politics: Neglecting Women's Diverse Realities}

New Order Indonesian politics in national development was not oriented to gender equity; and development was mainly meant economic growth. Like other developing countries pursuing industrialization for their development, Indonesia did not give priority to agriculture that had been the backbone of economic production. The shift of economic structure, from agriculture to industrialization affected women in several ways. Many women were forced to find jobs outside their villages to meet their needs, and many of them were pushed into factories. Women workers who had no skills had been kept working in factories under exploitative terms and conditions. Although the percentage of women attending schools had increased since the 1970s, it had always been fewer than that of men, particularly in the upper levels. One of the consequences was that the majority of women have been less competitive in the job market, and only gained marginalized positions in the growing industries as shown in studies by Diane Wolf. ${ }^{23}$

The government made effort to create national stability in order to maintain its economic development. In order to do so, the government was prepared to sacrifice people's political participation and supports by imposing restriction over social and political, as well as religious associations, which might voice different views and interests from those of the State. Women's organizations, which had been an important part in the Indonesian political struggle long before independence as pointed out by Cora Vreede-De Stuers, ${ }^{24}$ were tamed.

As soon as Soeharto took power in 1966, he banned the most militant women's organization of that day, Gerwani, because of its political affiliation with the Indonesian Communist Party. Following

${ }^{23}$ Diane Wolf, Factory Daughters: Gender, Household Dynamics and Rural Industrialization in Java (Berkeley: University of California Press, 1992).

${ }^{24}$ Cora Vreede-De Stuers, The Indonesian Women: Struggles and Achievements (The Hague: Mouton, 1960). 
its removal the regime systematically created a stigmatized label for women activists as immoral women who stepped outside the boundaries of their feminine nature. ${ }^{25}$ Alternatively, the State advertised systematically a new image of the ideal woman for Indonesians: a mother (ibu) who is submissive and apolitical - a notion that Djajadiningrat-Nieuwenhuis calls ibuism. ${ }^{26}$ To promote this homogenized womanhood the government sponsored the formation of several wives' organizations, such as Dharma Wanita (Women's Duties) for wives of men who were state employees, and Pembina Kesajahteraan Keluarga/PKK (Guidance of Family Welfare) for all women. ${ }^{27}$ Diverse gender roles assumed by Indonesia women from different regions or ethnic groups, such as in Java, Aceh and Bugis, had been disregarded. ${ }^{28}$

In 1970s the government launched the family planning program to overcome demographic and development problems. According to Adrina's research the family planning program was implemented to meet quantitative targets of decreasing women's fertility rate; hence it was women who became the sole object. ${ }^{29}$ To reach the number targeted some coercive methods were involved. There was evidence of women being implanted with IUDs without any informed consent. Those reluctant to adopt contraception were stigmatized as 'antidevelopment' or 'deviant'. ${ }^{30}$ Nevertheless, a number of social-economic

${ }^{25}$ Saskia Wieringa, Penghancuran Gerakan Perempuan di Indonesia (The Politization of Gender Relations in Indonesia. Women's Movement and Gerwani until the New Order State). Translated by Hersri Setiawan (Jakarta: Garba Budaya dan Kalyanamitra, 1999), p. 556.

${ }^{26}$ Julia Suryakusuma, "State Ibuism..."; and Madelon DjajadiningratNieuwenhuis, "Ibuism and priyayization: Path to Power" in Indonesian Women in Focus: Past and Present Notions, edited by E. Locher-Scholten and A. Niehof (Dordrect-Holland: Foris Publication, 1987).

${ }^{27}$ Sukanti Suryochondro, Potret Pergerakan Wanita Indonesia (Jakarta: Rajawali, 1984).

${ }^{28}$ Kathryn Robinson, "Gender, Islam and Culture in Indonesia" in Love, Sex and Power in Southeast Asia, edited by Susan Blackburn (Melbourne: Monash University Press, 2001).

${ }^{29}$ Adrina et al. Hak-hak Reproduksi Perempuan yang Terpasung (Jakarta: Pustaka Sinar Harapan bekerjasama dengan Program Kajian Wanita Universitas Indonesia dan the Ford Foundation, 1998), pp. 75-77.

${ }^{30}$ Adrina et al. Hak-bak Reproduksi Perempuan yang Terpasung, pp. 78-80; 96-98. 
benefits of the program have been enjoyed by Indonesian families: most significant have been decreased infant mortality rates, and the increased opportunity for capital and economic improvement. More personal advantages have also been gained by women from the program: by planning births, women could enjoy some freedom for their own body and time.

In 1974 the government passed a national marriage law, a demand which has been expressed by women since the late colonial period. In many ways, the law gives some protection to women against forced marriage and offers Muslim women rights to initiate divorce. However Kathryn Robinson noticed that the introduction of the law embodied political tactics of the New Order. ${ }^{31}$ While on the surface the government seemed to grant the demand of women for a marriage law, in fact the State implemented its own agenda of ideal womanhood. The law adopts a patriarchal family system in which a father is the head of the family who deserves some privileges not shared with his wife, such as to marry spouses and to easier conclude a divorce if his religion permits. A wife is primarily to take care of her husband's children and household. Based on such premises, in economic sector women's wages and income have been regarded as secondary in front of the law -hence women get paid less than men, regardless of their marital status, or whether a woman was a single parent or had unemployed husband for any reason.

There are plenty of evidences which show that Indonesian women were not merely accepting these State policies, rather they have sought ways of making their ideas and programs implemented. According to Darmiyanti Mukhtar's research the rise of women's NGOs adopting feminist theories to approach women's issues in Indonesia in the $1990 \mathrm{~s}$ was a real challenge for the New Order regime. ${ }^{32}$ In the next sections I examine how a long standing women's organisation has dealt with the New Order's gender politics.

${ }^{31}$ Kathryn Robinson, "Indonesian Women from Orde Baru to Reformasi" in Women in Asia: Tradition, Modernity and Globalisation, edited by L. Edwards and M. Roces (St Leonard: Allen and Unwin, 2000), pp. 147-148.

${ }^{32}$ Darmiyanti Mukhtar, "The Rise of the Indonesian Movement in the New Order State" a thesis submitted to Murdoch University, Australia, 1999. 


\section{Nasyiah: Muslim Young Women Organization}

Broadly speaking there are two categories of women's social organizations in Indonesia: one is called organisasi massa/ormas (massbased organization) and the other is lembaga swadaya masyarakat/LSM (known as NGO). ${ }^{33}$ Nasyiah is of the ormas type. Currently, the structural hierarchy of Nasyiah consists of five levels of leadership: national, provincial, municipal (kota and kabupaten), districts (kecamatan), and hamlets. Horizontally, the central executive office has five departments: social and economic affairs; dakwab (religious proliferation); documentation and information; art and culture; and the department of cadre or leadership. In the national office and in some provinces, Nasyiah has two other semi-independent institutions: one is in the form of a foundation (yayasan) to develop profitable businesses to fund organizational expenses, and the other is an institute (lembaga) dedicated to research and the development of women's resources.

Before it reached its current situation Nasyiah, as an organization, has evolved from being a simple group of a few Muslim girls in the Kauman quarter of Yogyakarta in 1919 called Siswa Praja Wanital $S P W$. The girls were pupils of Muhammadiyah Standard School, a fiveyear elementary school built in the mid of 1910s. The activities of SPW were conducted outside of class hours, and were focused to implement theoretical knowledge they learned into practice, such as how to conduct proper ablution and perform congregational praying. Apart from applying their religious and worldly knowledge in practice, through SPW the young girls developed sisterhood and solidarity, and later on they also learned practical skills necessary for Muslim girls, such as sewing, cooking, and knitting. ${ }^{34}$ Since it was not a common practice among Javanese for girls to attend school in the early twentiethcentury Indonesia, it was hard for these girls to have extra activities outside school and home. Through SPW the girls encouraged and supported each other when they encountered difficulties in their social interactions.

${ }^{33}$ Darmiyanti Mukhtar, "The Rise of the Indonesian Movement”, p. 131.

${ }^{34}$ Nur Aini Setiawati, "Sejarah Nasyiatul Aisyiyah di Kauman 1919-1965" a thesis submitted to Gadjah Mada University, Indonesia, 1985. 
Cultural beliefs regarding women's appropriate place in society held by most Javanese people, including Muslims, was that their place was in either their parents' or their husbands' houses..$^{35} \mathrm{~A}$ woman, as a member of a family, had practically no rights to make important decisions for her life. Her fate was dependent on her male relatives, as expressed in a Javanese motto "wadon iku suwargo nunut neraka katut" (a woman is carried to heaven and dragged to hell). Raden Ajeng Kartini, known as a Javanese feminist, experienced such discrimination, particularly in terms of exercising her rights to pursue higher education, employment and marriage throughout her adult life. ${ }^{36}$ While Kartini was confident in criticising the feudal culture adopted by Javanese, and the ignorance in the part of Javanese women as the main causes for women's suffering and inferior status, Kyai Haji Ahmad Dahlan, the founder in 1912of a reformist Islamic organization Muhammadiyah, propagated a more religious view to improve women's conditions in early twentieth century Indonesia.

Having studied the Qur'anic verses speaking about women Kyai Dahlan began to give more attention to women's issues in religious perspectives. He began inviting women from his own close families and neighbours to his lectures, and trained them to be the future leaders of Muslim women. He urged Muhammadiyah members to provide support for their wives and daughters to learn religion, and to obtain better formal education. After two years of persuasion, many Muslim men were convinced that women have the rights to earn heavenly rewards of their own without being dependent on their parents or husbands. So, they allowed their wives to seek knowledge in a women's group of Sapa Tresna (Who Love) founded in 1914 by Kyai Dahlan's female pupils, and sent their daughters to attend Muhammadiyah schools built since mid 1910s. ${ }^{37}$

Having been given an opportunity to access religious and worldly knowledge through women's groups and schools, Muslim women educated themselves and developed other skills they found important

\footnotetext{
${ }^{35}$ Koentjaraningrat, Kebudayaan Jawa (Jakarta: Balai Pustaka, 1984), p. 245.

${ }^{36}$ Haryati Soebadio and Saparinah Sadli, Kartini Pribadi Mandiri (Jakarta: Gramedia, 1990).

${ }^{37}$ Nur Aini Setiawati, “Sejarah Nasyiatul Aisyiyah di Kauman”, p.4.
} 
to improve women's conditions in society. Clearly, both women of Sapa Tresna and young girls in SPW learned more than what were taught by their male teachers, and they utilized their independent agency to promote social changes and wider space for women's involvement in societies.

In 1917, as Sapa Tresna had spread to regions outside Yogyakarta principality, it was decided to officially unify with Muhammadiyah, and find a new name which might be acceptable to members from outside Java. Hence the name of Aisyiyah was adopted. Aisyiyah derives from Arabic and signifies those who embrace the qualities of Aisyah, the beloved wife of the Prophet Muhammad. Obviously, the women of Sapa Tresna viewed Aisyah as a perfect model of Islamic womanhood; accordingly it was hoped that women of Aisyiyah would embrace the excellent characteristics of Aisyah, who was known to be loving, caring, active, smart, knowledgeable, productive and full of courage..$^{38}$ Aisyah was also one of the most trustworthy and reliable sources of hadith and an advisor to early Muslim leaders. It was also reported that the Prophet designated Aisyah as a religious authority when he said: 'Take half of your religion from this ruddy-complexioned women'. ${ }^{39}$

Following the amalgamation with Muhammadiyah, Aisyiyah expanded rapidly in regions outside Java. As the development of Muhammadiyah schools was not as fast as that of Muhammadiyah's branches, in 1923 the girls of SPW decided to align with Aisyiyah in order to be able to reach broader audience of young girls to also include those already left primary schools as well as those who never attended any formal education, which constituted the biggest number. On 16 May 1931, the name of SPW was changed to become Nasyiatul Aisyiyah (young generation of Aisyiyah) which reflected its larger

${ }^{38}$ Kuntowijoyo, "Arah Pengembangan Organisasi Wanita Islam Indonesia: Kemungkinan-kemungkinannya" in Wanita Islam Indonesia dalam Kajian Tekstual dan Kontekstual, edited by L. Marcus-Natsir and J.H. Meuleman (Jakarta: INIS, 1993), pp. 129-130.

${ }^{39}$ Fatima Mernissi, Women and Islam, pp. 5-7, 55-58; Azizah Al-Hibri, ed., Women and Islam (Oxford: Pergamon, 1982), p 213. 
audience. Thus, the year of 1931 is commemorated as the birth date of Nasyiah. ${ }^{40}$

During the period between the 1930s and 1965, with a major interruption during the 1940s due to World War II and the Revolution, Nasyiah developed three groups to serve girls' interests. Because age was a significant factor in determining youth, Nasyiah made group classification based on age. For girls aged 7-10 years Nasyiah created Jamiatul Athfal (Children's Group), in which the children received lessons in reciting the Qur'an, singing, training in hand-crafts and sports. For girls aged between 10 to 15 years, there was a group called Tajmilul Akblak (Refining the Character) in which they were learning Islamic teachings on women's virtues. In this group they also began learning and practising public speaking as a preparation to become a muballighat (women preachers). Some simple life skills, such as cooking, knitting and sewing were also imparted to the group. The third group, Thalabus Saadah (Quest of Happiness), was for girls aged 15 years and above. Here, the discussion of Islamic family laws, and codes of conduct for establishing a happy family were given emphasis. They also began practising giving tabligh (religious speeches) in women's pengajian (informal religious gatherings for reciting the Qur'an and other learning purposes). The girls were also given training on administration of the organization so that they might continue the endeavour of the organization in the future. There was also a group for everyone, called Dirasatul Banat (Girls' Studies) whose activity mainly consisted of reading the Qur'an for girls of all ages in the evenings. ${ }^{41}$

Maintaining its religious origin, Nasyiah after gaining autonomous status form Aisyiyah in 1965, has reconfirmed Islam as the most important source of values in dealing with issues of young women, as stated in its constitution updated from one muktamar (highest rank of

${ }^{40}$ PP Nasyiatul Aisyiyah, Riwayat Singkat Nasyiatul Aisyiyah dan Khittah Perjuangannya (Yogyakarta: PP Nasyiatul Aisyiyah PP Nasyiatul Aisyiyah, 1996b), p. 46.

${ }^{41}$ PP Nasyiatul Aisyiyah, Nasyiatul Aisyiyah, Riwayat Singkat, Khittah Perjuangan dan Kepribadiannya (Yogyakarta: PP Nasyiatul Aisyiyah, 1999b), p.7; Yusuf Abdullah Puar, Perjuangan dan Pengabdian Mubammadiyah (Jakarta: Pustaka Antara, 1989), p. 247. 
its national congress) to another. ${ }^{42}$ While upholding Islamic teachings, they take into consideration the cultural, social and political changes experienced by Indonesians during the course of its history, which have influenced the lives and realities of young women. This kind of step reflected the ideas proposed by Rahman when he asserts that Muslims should proceed by means of a double movement in order to grasp the meaning of Qur'anic massage which is relevant to the condition of the world today. ${ }^{43}$ Therefore it is not surprising that we find Nasyiah in the turn of the twenty first century as presented earlier in this section has changed much from its original form.

\section{E. Nasyiah's Strategy to Advance Women's Interests during the New Order Regime}

Religions have different influences over different regimes, communities or even individual people. While in its first 15 years the New Order viewed Islam as a political threat, ${ }^{44}$ for Nasyiah it has always been an important source of values for improving women's lives. Unlike many women's NGOs that develop their approach to women's issues using social and developmental theories, ${ }^{45}$ Nasyiah consults Qur'anic values in its elaboration of the concept of development and women's role.

Unlike the New Order regime which equated national development mainly with economic growth, Nasyiah holds a broader view of development, that it is as an effort to create a prosperous community. The notion of prosperous community itself is driven by a normative image, which in Qur'anic terms is expressed as 'ummatan wasatha' (a community justly balanced) as mentioned in al-Baqarah 143 and 'baldah tayyibah wa-rabb ghafur' (a territory fair and happy, and a Lord Oft-Forgiving) mentioned in Saba 15, as clearly expressed in

${ }^{42}$ See PP Nasyiatul Aisyiyah, Anggaran Dasar dan Anggaran Rumah Tangga Nasyiatul Aisyiyah (Yogyakarta: PP Nasyiatul Aisyiyah, 1976); (1988); (2001).

${ }^{43}$ Fazlu Rahman, Islam and Modernity, p. 5.

${ }^{44}$ M.Syafi'I Anwar, Pemikiran dan Aksi Islam: Sebuah Kajian Politik. Tentang Cendekiawan Muslim Orde Baru (Jakarta: Penerbit Paramadina, 1995).

${ }^{45}$ See Darmiyanti Mukhtar, "The Rise of the Indonesian Women Movement". 
the prelude of Nasyiah's legislation. ${ }^{46}$ This is however not to imply that Nasyiah disregards economic prosperity: in fact, in 1990 it developed a department for social and economic affairs. The question then is how this ideal, a good community, should be translated in its programs and in women's daily life, and within the limited space available during the undemocratic New Order government?

Despite its different view on issues of women in development, Nasyiah did not openly criticise or challenge the government's agenda, as some Indonesian feminist NGOs did. ${ }^{47}$ Nasyiah women seemed more comfortable to take an independent position to nurture their programs for young women without involving themselves directly in the open debates on gender politics and development. This approach by Nasyiah can be seen from the following major organizational decisions. As soon as it became independent from Aisyiyah in 1965, Nasyiah formulated its organizational goals which reflected its concern for young women. The document explicitly made no single reference to ibuism ideology as in the case of New Order's gender politics. ${ }^{48}$

During the period between 1965 and 1985 Nasyiah installed four departments to implement its program for young women: kader/ leadership training, dakwah (religious proliferation), family welfare, and information. ${ }^{49}$ The department of kader was responsible for educating young Nasyiah women to continue the leadership of the organization. All leaders were expected to internalize the kepribadian (personality) of Nasyiah which was formulated in its muktamar held in 1968, and

\footnotetext{
${ }^{46}$ PP Nasyiatul Aisyiyah, Anggaran Dasar.

${ }^{47}$ Darmiyanti Mukhtar, “The Rise of the Indonesian Women Movement”, pp.
} 103-112.

8 The main goals of Nasyiah from 1965-1985 were as follows: 1 ) to educate its members so that they become putri Islam sejati (sincere young Muslim women); 2) to train its members to become qualified muballighat (women preachers); 3 ) to develop young women's creativity and skills; 4) to train young woman to become young leaders for the cause of Islam, organization and community at large; 5) to reconfirm Nasyiah's position as the women cadre of Muhammadiyah and Aisyiyah; 6) to establish sisterhood amongst Muslim women (Pimpinan Pusat Nasyiatul Aisyiyah 1976).

${ }^{49}$ PP Nasyiatul Aisyiyah, Anggaran Dasar. 
was reconfirmed in the subsequent congresses. ${ }^{50}$ The traits and ethical virtues sought after were derived from Qur'anic verses. Foremost, Nasyiah believed that human life should be based on taubid (pure monotheism) and keikhlasan (sincere devotion to God). Nasyiah should embrace hikmah (wisdom), patience and persistence, open mindedness and knowledge. ${ }^{51}$ From this vision of Nasyiah's 'personality' it was very obvious that Nasyiah women had envisioned a different type of womanhood from the submissive and a-political promoted by the New Order government. While the New Order government in its early phase was rather hostile to ideas associated with Islam, Nasyiah stood firm in its reliance on Islam. Nasyiah women had interpreted the Quránic message in such a way that it became a relevant source of value and support to their struggle for creating spaces for young women and improving their conditions during those years.

In order to help Nasyiah women to internalise these noble characters, the organization developed leadership training manuals,

${ }^{50}$ PP Nasyiatul Aisyiyah, Nasyiatul Aisyiyab: Riwayat Singkat, Kbittah Perjuangan dan Kepribadian, p. 33.

${ }^{51}$ The followings are Qur'anic verses used as sources of the traits. The Qur'an Al-D zariyat 56: "I have only created jinns and men, that They may serve Me"; $A l$ Bayyinah 5: "And they have been commanded no more than this: to worship Allah, offering Him sincere devotion, being true in faith; to establish regular prayers, and to practice regular charity, and that is the religion right and straight"; $A n-N a b l 125$ : "Invite (all) to the way of thy Lord with wisdom and beautiful preaching, and argue with them in ways that are best and most gracious, for thy Lord knowest best who have strayed from His Path, and who receive guidance"; Al-Baqarab 153: "O ye who believe! Seek help with patient perseverance and prayer, for Allah is with those who patiently persevere"; Al-Mujadalah 11: "O ye who believe! When ye are told to make room in the assemblies, (spread out and) make room, (ample) room will Allah provide for you. And when ye are told to rise up, rise up; Allah will raise up to (suitable) ranks (and degrees) those of you who believe and who have been granted (mystic) knowledge. And Allah is wellacquainted with all ye do"; chapter Al-Zumar 9: "Is one who worships devoutly during the hours of the night prostrating himself or standing (in adoration), who takes heed of the Hereafter, and who places his hope in the Mercy of his Lord -(like one who does not0? Say: 'are those equal, those who know and those who do not know? It is those who are endued with understanding that receive admonition." PP Nasyiatul Aisyiyah, Konsepsi Pribadi Putri Muslim (Yogyakarta: PP Nasyiatul Aisyiyah, 1968), pp. 2-4 ; PP Nasyiatul Aisyiyah, Nasyiatul Aisyiyab: Riwayat Singkat, pp. 40-59. 
and updated as well as revised them over time since 1971, so that they will suit the current needs and situations of young women. There were three types of leadership training adopted by Nasyiah: formal, non formal and informal. The formal training was called Darul Arqam Nasyiatul Aisyiyah/DANA, ${ }^{52}$ and the syllabus was mainly on Islamic teachings, philosophy and the ideology of womanhood adopted Nasyiah. All women who were going to assume leadership should pass the DANA training. The non formal leadership training was developed to enhance the capacity and capability of Nasyiah women in certain areas prioritised by the organization in a particular period; so the kinds of focus might vary from one period to another. Since 1985, Nasyiah has released five different non formal training 'packages': training in muballighat (religious deliverance), entrepreneurship, sakinah (happy, harmonious and peaceful) family, journalism, and politics/voter education. Members could choose the training alternative that suited their own interests and needs. Members were also allowed to participate in more than one training given if there were spaces available. Informal leadership training was aimed at upgrading and refreshing the organizational dynamics and was held by local Nasyiah according to their local, particular needs. ${ }^{53}$

The dakwah activities were seen as an important method for spreading the organization's mission as an Islamic association for young women. Since 1965, it enacted the department of dakwah and improved it over time. The department was responsible not only for maintaining Nasyiah members' connection with Islamic tradition, but also for creating a situation in which performing religious duties should be a happy and rewarding endeavour. The department also provided training for muballighat (women preachers) who communicated Nasyiah's vision and missions to a larger audience of young women through the most

${ }^{52}$ Darul Arqam, taken from Arabic term literally means the House of Arqam, is a formal training 'package' compulsory for all women who are assuming leadership in Nasyiah. There are two levels of $D A N A$. Back to the historical course of the Prophet's time, the Prophet used to train and teach his followers in the house of Arqam, one of his companions, during the difficult time when the Muslims were boycotted by the pagans of Mecca.

${ }^{53}$ PP Nasyiatul Aisyiyah, Sistem Perkaderan Nasyiatul Aisyiyah (Yogyakarta: PP Nasyiatul Aisyiyah, 2003), pp. 29-32. 
popular informal learning forum called pengajian (literally means 'reading' or 'study'). In early 1990s Nasyiah launched a program called integrated dakwah, which had various themes and activities, such as tabligh (preaching) in young women's groups, preaching through radio and TV stations, delivering messages in printed media, and providing youth counselling. ${ }^{54}$

In 1990-1995 the major theme of the Dakwah Department was 'women, health and environment' (Pimpinan Pusat Nasyiatul Aisyiyah 1998:15-16). Judged from the themes selected, it seemed that Nasyiah was among the women's organizations which responded to the emerging issues of women's reproductive rights and health as a direct criticism to the New Order's family planning program which was using a quantitative approach as explained earlier. The themes also show that Nasyiah has a concern for environmental problems faced by the nation, although organizationally it has not developed a specific department to deal with the issues.

While articulating some different aspirations from those of the State on young women's issues, Nasyiah was directly influenced by the New Order government policies. Many of its members were also involved in State-sponsored organizations, such as KNPI (Indonesian Youth National Committee) and PKK, consequently Nasyiah members have to some extent absorbed and internalised New Order's gender ideology, and were not interested to challenge it. Unlike many women's NGOs, which criticized and opposed the government openly through the mass media and by conducting strikes, ${ }^{55}$ Nasyiah employed more cooperative ways of spreading their ideas within the government policy corridors. Although mass-based women's organizations like Aisyiyah, Nasyiah, Dharma Wanita and PKK have been criticized by many writers for being conservative and instruments of the State, ${ }^{56}$ they did in fact

${ }^{54}$ PP Nasyiatul Aisyiyah, Pedoman Umum Program Dakwah Terpadu Nasyiatul Aisyiyah (Yogyakarta: PP Nasyiatul Aisyiyah, 1998), pp. 13-16.

${ }^{55}$ Darmiyanti Mukhtar, “The Rise of Indonesian Women Movement”, pp. 111.

${ }^{56}$ Nelly van Doorn-Harder, "Between Rhetoric and Reality: Aisyiyah Women Coping with Modernization and Change". Paper read at AAS Conference 1999, at Boston, USA, p. 2; Julia Suryakusuma, "State Ibuism," p. 54. 
advance some interests of women within their own limits and capacities. For women who had been preoccupied by their household chores, being involved in their husbands' office of Dharma Wanita gave them a legitimate break to leave their domestic burdens for a while, and also gave them an opportunity to meet other women, as well as to learn how to run an organization. ${ }^{57}$

Apparently influenced by the New Order's long term development program, in a congress in 1985 Nasyiah also developed a 25 year program covering the period from 1985 to $2010 .{ }^{58} \mathrm{Few}$ women's NGOs have such a long-term vision. It was agreed that Nasyiah leadership in the period 1985 to 1990 would focus its energy on building a strong base of leadership training (kaderisasi) through DANA. ${ }^{59}$ The 1990-1995 leadership terms concentrated on kemuballighatan, i.e. enhancing Nasyiah women's capacity to reach broader audience of young women through various programs, then followed by a period of 1995-2000 which focused on improving Nasyiah's engagement with social issues (kemasyarakatan) faced by young women of that time, under the management of the department of dakwah and social-economic affairs respectively. In the period 2000 to 2005 Nasyiah concentrates on maximizing its contribution to solve some national problems, not only those affecting Muslim women but also all young Indonesian women. It is expected that Nasyiah establishes contacts and networks with other women's organizations or institutions, and wider societies interested in issues faced by young women. During the last five years covering the period from 2005 to 2010 Nasyiah is expecting to engage

${ }^{57}$ Binny Buchory and Ifa Soenarto, "Dharma Wanita: An Asset or a Curse? In Indonesian Women: The Journey Continues, edited by M. Oey-Gardiner and C. Bianpoen, eds (Canberra: Research School of Pacific and Asian Studies, The Australian National University, 2000), pp. 145-155.

${ }^{58}$ PP Nasyiatul Aisyiyah, "Keputusan Musyawarah Nasional Nasyiatul Aisyiyah II Periode 1990-1995”, pp. 9-10; 21-22.

${ }^{59}$ DANA is abbreviation of Darul Arqam Nasyiatul Aisyiyah, a formal organisational training for Nasyiah who are assuming leadership position within the organisation. 
in a program which has an international scope (internasionalisasi). ${ }^{60} \mathrm{It}$ is very clear from their long-term 25 year plan started in 1985 that Nasyiah women have projected a variety of roles for young women ranging from self-enhancement and social activism to developing national and international involvement and network building with other women activists.

The early phase of Nasyiah autonomy from 1965 to 1985 coincided with the period in which the New Order government developed its power and social control. In fact as soon as Nasyiah women succeeded in gaining independent status from Aisyiyah in 1965, they faced organizational both internal and external challenges. Internally, Nasyiah experienced a strained relationship with its 'maternal' organization, Aisyiyah, due to its new approaches to young women's issues. ${ }^{61}$ Externally, Nasyiah was facing a regime which applied strong restrictions on social and political associations, and in particular was not friendly to any Islamic symbols and organizations. ${ }^{62}$

Learning from its previous success in advancing its demand for autonomy from Aisyiyah, Nasyiah seemed to take a similar strategy to survive and be able to run its own agenda within the confines of New Order control. The strategy Nasyiah applied was to show the similarities between Nasyiah's and the other parties' agenda, and to focus on the successes and positive sides of their platforms, rather than pointing out the differences and passing harsh criticism. Such subtle ways of communications within organisation have been practiced by Nasyiah women, and they have found them quite successful in serving their

${ }^{60}$ In Nasyiah national congress held in Jakarta in 2000, it was agreed that its national leadership should be changed from five years to four years, see PPNasyiatul Aisyiyah, Anggaran Dasar dan Anggaran Rumah Tangga. Therefore the leadership term should be 2000-2004 and 2004-2008 when there is no further change in this matter.

${ }^{61}$ There were a number of organizational and 'psychological' issues which became the sources of conflicts between Nasyiah and Aisyiyah in its early phase of autonomy, as explained by Sulistyawati, Nasyiah national chief executive from 1971-1985 (interview, 10.09.2003). I elaborate these problems further in my work "A Daughter in the Indonesian Muhammadiyah: Nasyiatul Aisyiyah Negotiates Its New Status and Image" in Oxford Journal of Islamic Studies 18:1 (2007), pp. 69-94.

${ }^{62}$ M. Syafi'i Anwar, Pemikiran dan Aksi Islam. 
interests so far as stated by Siti Chamamah. ${ }^{63}$ Organizational communications which involved open and direct criticism of both internal (Nasyiah, Aisyiyah and Muhammadiyah) and external (such as government offices, foreign embassies) policies and practices only began to be adopted by Nasyiah executives in the early 1990s, as explained by Trias Setiawati, Nasyiah chief executive 2000-2004:

When I joined Nasyiah in 1985, I noticed that certain ways of communication prevailed in the organization. The practice of "Javanese" politeness was very dominant such as low voices and no open opposition or criticism. Seniority, close relationships with Muhammadiyah and loyalty were highly valued. The atmosphere began to change in the 1990s, Nasyiah became more open and egalitarian. This is probably because there are new Nasyiah members who were experienced in student organizations or other NGOs, and they introduced new atmosphere in Nasyiah. ${ }^{64}$

Unsurprisingly, while Nasyiah was under the strict control of the New Order regime it took a strategy of strengthening its internal resource and organizational instruments rather than outwardly challenging the government. From the discussion it is obvious that there are differences in the ways Nasyiah and other women's NGOs deliver their critics or disagreements; Nasyiah is more subtle and applies a psychological approach while some other women's NGOs are more direct and employ legalistic and political approaches.

In 1971 Nasyiah renamed the department of keputrian (young womanhood) to become the department of kesejabteraan keluarga (family welfare) ${ }^{65}$ Despite the similarity in name, unlike the State-sponsored PKK (guidance of family welfare) which spread the ideology of submissive and apolitical motherhood, Nasyiah propagated a faithful, active and economically independent, yet loving motherhood within

${ }^{63}$ Interview with Siti Chamamah, 08.10.2003.

${ }^{64}$ Interview 15.09.2003.

${ }^{65}$ According to Sulistyowati, the department of keputrian was renamed because it only concentrated on women's life skills. Under her leadership, it was designed that the department would expand its coverage, so it was renamed the Department of Family Welfare (Interview, 06.08.2003). 
the confine of sakinah (peaceful and happy) family. ${ }^{66}$ The idea of the sakinah family adopted by Nasyiah was developed mainly by Aisyiyah and Muhammadiyah, before it was borrowed by the New Order government to promote a new image of family welfare to replace the deteriorating icon of family planning policy in 1990. Although Nasyiah did not totally oppose the New Order family planning program, it applied a different perspective in approaching the key issues, such as in selecting appropriate contraceptive methods, and considering side effects, specific women's needs and priorities, as well as the size of family. While in its early phase, the government focused on pregnancy reduction and quantitative target, which in many cases involved violating women's dignity and rights, ${ }^{67}$ Nasyiah promoted family planning for the betterment of women's health, the quality of offspring, and consideration of afterlife consequences, ${ }^{68}$ as stated in al-Nisä: $9-10 .{ }^{69}$ Nasyiah assumed that different women and families might have different priorities and capabilities; therefore the messages and methods of family planning delivered would differ from one group to another, as explained by Sulistyowati, the chief of the Nasyiah Central Executive form 1971-1985. ${ }^{70}$ This way Nasyiah was able to advance its mission women's health and family affairs while at the same time it did not create an open conflict with the government.

Since 1995 Nasyiah's Department of Family Welfare was given a broader mandate as to also include managing social and economic programs. While the department still maintained its training activities of building the sakinah family, it was also responsible for carrying out

${ }^{66}$ Interview with Sulistyowati, 10.09.2003.

${ }^{67}$ Adrina et al. Hak-bake Reproduksi Perempuan yang Terpasung (Jakarta: Pustaka Sinar Harapan bekerjasama dengan Program Kajian Wanita Universitas Indonesia and the Ford Foundation), pp. 78-80; 96-98.

${ }^{68}$ Nasyiah believes that parents have the responsibility to educate their children in the name of God, and they will be accounted in how well they educated their children in the afterlife.

69 "Let those (disposing of an estate) have the same fear in their minds as they would have for their own if they had left a helpless family behind: let them fear Allah, and speak words of appropriate (comfort). Those who unjustly eat up the property of orphans, eat up a fire into their own bellies, they will soon be enduring a blazing fire."

${ }^{70}$ Interview, 10.09.2003. 
programs to improve social and economic conditions for women and the community, such as facilitating entrepreneurship training for young women. Unlike the New Order government which favoured big business based on foreign debt and the capitalist system, Nasyiah and its community installed economic organs which they need and can manage, such as small scale cooperatives, and developed small business networks and non banking financial institutions which do not conflict with religion.

During the period of 1995-2000 Nasyiah identified that empowering women in politics and economic affairs was crucial and important. Hence during this course of time Nasyiah developed two major agendas on pendidikan politik (political education) and pelatiban kewirausabaan (entrepreneurship training) for young women. In those years Nasyiah conducted a program of pengajian politik, in which it collaborated with a foreign donor, The Asia Foundation. ${ }^{71}$

The longevity of Nasyiah shows the support from local women who share similar values and interests. Unlike the New Order Statesponsored organizations and some NGOs which used a top-down approach to recruit members and decide on programs, Nasyiah's constitution favours bottom-up process. Unlike the State-sponsored women's organizations in which membership was obligatory, Nasyiah has always been a voluntary association. In most activities members have acted as both the providers as well as the recipients of the programs. Such an interchangeable position was very possible because of the ranges of ages and programs adopted by Nasyiah. No financial payment has been provided for doing all the organizing or teaching in Nasyiah. Instead these women have expected heavenly rewards only from God, which they feel spiritually very rewarding and satisfying. ${ }^{72}$ From the way they associate themselves, how they articulate their needs and develop programs to meet them, Nasyiah women in fact have implemented the notion of women's independent agency.

${ }^{71}$ PP Nasyiatul Aisyiyah, Materi Pendidikan Politik Bagi Perempuan Pemilih (Yogyakarta: PP Nasyiatul Aisyiyah, 1999).

${ }^{72}$ The specific Islamic term they used to describe their intention was ikblas lillahi ta'ala (sincere devotion to God the Almighty) (Interview with Ibu Dalalah 08.10.2003). 
The creation of new branches is possible only when there are local women who request that, as stated in the constitution article 14. Official recognition of new branches is given by Nasyiah central executive when these women have showed their commitment and conducted activities that benefited their community, such as setting up pengajian or other learning resources, micro finance institutions, cooperatives, and women's group to combat smoking and alcohol, to mention a few. It is the local women themselves who create their own programs to meet what they need in particular circumstances and time. The central leadership only provides a broad guideline for local committees. Accordingly, it is very common to find different branches of Nasyiah offering different programs according to the needs and capabilities of their local communities.

Since its autonomy in 1965, Nasyiah has implemented the practice of election and deliberations in choosing their leader and making decisions as governed by its regulation article 10. In times when the women of Nasyiah experience difficulties or conflicts of interests, they seek counsel in religion. Devotion to God inspires their involvement in the organization, and such divine intention should not be undermined by personal greed. ${ }^{73}$

Always believing that God will show the way enables these women to endure any difficulties. These organizational ethics of conduct are inspired by the Qur'anic message in chapter Ali Imran 159 $160 .{ }^{74} \mathrm{It}$ is probably because of these religious convictions that Nasyiah has not fragmented as many women's NGOs do whenever they face internal conflicts and difficulties; they put religious motivation far higher than earthly intention.

${ }^{73}$ Interview with Sulistyowati 10.09.2003.

74 "It is part of the Mercy of Allah that thou dost deal gently with them. Wert thou severe or harsh-hearted, they would have broken away from about thee: so pass over (their faults), and ask forgiveness for them, and consult them in affairs (of moment). Then, when thou hast taken decision, put thy trust in Allah, for Allah loves those who put their trust in (in Him). If Allah helps you, none can overcome you; if He forsakes you, who is there, after that, that can help you? In Allah, then, let believers put their trust". 


\section{F. Conclusion}

In this paper the role of religion (Islam) and the gender politics of the New Order government of Indonesia in interpreting the construction of ideal womanhood are highlighted. While in some Muslim countries, such as Iran and Saudi Arabia, Islam has been projected as the reason for discriminatory laws applied in both countries, some groups of Indonesian Muslims have regarded Islam as an inspiration for the improvement of women's status and life in society, as exemplified by the action of Kyai Haji Ahmad Dahlan which was supported by the women of Nasyiah. This case shows clearly that religion has had different influences on different societies or people; and there are other factors which might contribute to the determination of women's fate in certain countries, such as the politics of the regime in power. Indonesia has never been an Islamic state, yet it has not been very 'friendly' with women. The New Order regime was very restrictive towards social and political organization, particularly women's political movement. In order to 'tame' women's political militancy, the government promoted an ideal womanhood for every Indonesian woman, who was domesticated, subordinated to her husband, family, and society, who never questioned her political rights. The New Order's policies for women in general were not oriented towards gender justice, as illustrated by the cases of family planning and marital law.

By the early 1990s when Soeharto was quite confident about the safety of his presidency, he opened up some space for other voices to emerge, known as the era of keterbukaan (openness). Taking advantage of this event, and due to the flows of foreign funds for developmental programs, Indonesian women founded various women's NGOs to better serve women's needs and interests. Many of these women's NGOs challenged the policy of the State by organising street demonstrations, and criticising the government in public and in the mass media. Although Nasyiah women worked with these women's NGOs on some women's issues, they took a different path in serving the needs and interests of young women. Rather than openly criticising and chellenging the government's policies, Nasyiah applied strategies of building its own internal women resources. It developed different departments and various 'packages' of training for women, such as 
Siti Syamsiyatun

entrepreneurship for women, political education, and journalism which might give women power and independency to establish their own life. Unlike the State-sponsored organizations, such as Dharma Wanita and PKK, membership within Nasyiah has been voluntary. It seems that Nasyiah avoided making direct confrontation with the New Order regime as to safeguard its existence in the long term, just as it did when Nasyiah faces conflict of interest with its paternal and maternal organizations, Muhammadiyah and Aisyiyah. Instead of applying feminist jargon as some women's NGOs did, Nasyiah employed religious terms to enhance the cause of Indonesian young women. 


\section{BIBLIOGRAPHY}

Adeney, Frances S., Christian Women in Indonesia: A Narrative Study of Gender and Religion, New York: Syracuse, 2003.

Adrina et al., Hak-hak Reproduksi Perempuan yang Terpasung, Jakarta: Pustaka Sinar Harapan bekerjasama dengan Program Kajian Wanita Universitas Indonesia dan the Ford Foundation, 1998.

Al-Hibri, Azizah Al-Hibri (ed.), Women and Islam, Oxford: Pergamon, 1982.

Ali, Azra Asghari, The Emergence of Feminism Among Indian Muslim Women 1920-1947, Oxford: Oxford University Press, 2000.

Anwar, M.Syafi'i, Pemikiran dan Aksi Islam: Sebuah Kajian Politik Tentang Cendikiawan Muslim Orde Baru, Jakarta: Penerbit Paramadina, 1995.

Barton, Greg, "Islam and Politics in the Newv Indonesia" in Islam in Asia: Changing Political Realities, edited by J.F. Isaacson and C. Rubenstein, New Brunswick: Transaction Publishers, 2002.

Buchory, Binny and Ifa Soenarto, "Dharma Wanita: An Asset or a Curse? In Indonesian Women: The Journey Continues, edited by M. OeyGardiner and C. Bianpoen, eds, Canberra: Research School of Pacific and Asian Studies, The Australian National University, 2000

Djajadiningrat-Nieuwenhuis, Madelon, "Ibuism and priyayization: Path to Power" in Indonesian Women in Focus: Past and Present Notions, edited by E. Locher-Scholten and A. Niehof, Dordrect-Holland: Foris Publication, 1987.

Doumato, Eleanor Abdella, "Education in Saudi Arabia: Gender, Jobs, and the Price of Religion" in Women and Globalization in the Arab Middle East: Gender, Economy and Society, edited by E.A. Doumato and M.P. Posusney, Boulder, Colorado: Lynne Rienner Publishers, 2003.

Dzuhayatin, Siti Ruhaini et al, Rekonstruksi Metodologis Wacana Kesetaraan Gender dalam Islam, Yogyakarta: PSW UIN Sunan Kalijaga, McGillCIDA dan Pustaka Pelajar, 2002. 
Faqihuddin Abdul Kadir, ed. Figh Perempuan: Refleksi Kyai atas WacanaAgama dan Gender, Yogyakarta: Rahima, the Ford Foundation, LKiS, 2001.

Feillard, Andrée, "Traditionalist Islam and the Army in Indonesia's New Order: the Awkward Relationship" in Nabdlatul Ulama, Traditional Islam and Modernity, edited by G. Barton and G. Fealy, Clayton, VIC: Monash Asia Institute, 1996.

Hassan, Muhammad Kamal, Muslim Ontellectual Responses to New Order Modern ization in Indonesia, Kuala Lumpur: Dewan Bahasa dan Pustaka Kementrian Pelajar Malaysia, 1982.

Ilyas, Hamim et al, Perempuan Tertindas: Kajian Hadis 'Misoginis', Yogyakarta: PSW UIN Sunan Kalijaga bekerjasma dengan the Ford Foundation, 2003.

Ilyas, Yunahar, Feminisme dalam Kajian Tafsir Qur'an Klasik dan Kontemporer, Yogyakarta: Pustaka Pelajar, 1997.

Jamhari and Ismatu Ropi et al., Citra Perempuan dalam Islam: Pandangan

Ormas Keagamaan, Jakarta: Gramedia Pustaka Utama, 2003.

Jayawardena, Kumari, Feminism and Nationalism in the Third World, London: Zed Books, 1986.

Kandiyoti, Deniz (ed.), "Introduction" in Women, Islam and the State, London: Macmillan, 1991.

Karam, Azza M., Women, Islamism and the State: Contemporary Feminism in Egypt, London: Macmillan Press Ltd, 1998.

Kazemzadeh, Masoud, Islamic Fundamentalism, Feminism, and Gender Inequality in Iran under Khomeini, Lanham, Maryland: University Press of America, 2002.

Koentjaraningrat, Kebudayaan Jawa, Jakarta: Balai Pustaka, 1984.

Kuntowijoyo, "Arah Pengembangan Organisasi Wanita Islam Indonesia: Kemungkinan-kemungkinannya" in Wanita Islam Indonesia dalam Kajian Tekstual dan Kontekstual, edited by L. Marcus-Natsir and J.H. Meuleman, Jakarta: INIS, 1993. 
Martyn, Elizabeth, "Gender, Nation in a New Democracy: Indonesian Women's Organizations in the 1950s", Dissertation submitted to Monash University, Australia, 2001.

Mernissi, Fatima, Women and Islam: An Historical and Theological Enquiry. Translated by M. JoLakeland, Oxford: Basil Blackwell, 1991.

Mietzner, Marcus, "Nationalism and Islamic Politics: Political Islam in the post-Soeharto Era" in Reformasi: Crisis and Changes in Indonesia, edited by A. Budiman, B. Hartley, D. Kingsbury, Clayton, VIC: Monash Asia Institute, 1999.

Moghadam,Valentine M. Modernizing Women: Gender and Social Change in the Middle East, Boulder, Colorado: Lynne Rienner Publishers, 2003.

Mukhtar, Darmiyanti, "The Rise of the Indonesian Movement in the New Order State" a thesis submitted to Murdoch University, Australia, 1999.

Mulia, Siti Musdah, Pandangan Islam tentang Poligami, Jakarta: Lembaga Kajian Agama dan Jender, Solidaritas Perempuan dan the Asia Foundation, 1999.

Nelly van Doorn-Harder, "Between Rhetoric and Reality: Aisyiyah Women Coping with Modernization and Change". Paper read at AAS Conference 1999, at Boston, USA.

PP Nasyiatul Aisyiyah, Anggaran Dasar dan Anggaran Rumah Tangga, Yogyakarta: PP Nasyiatul Aisyiyah, 2000.

----, Nasyiatul Aisyiyah, Riwayat Singkat, Khittah Perjuangan dan Kepribadiannya, Yogyakarta: PP Nasyiatul Aisyiyah, 1999.

----, Konsepsi Pribadi Putri Muslim, Yogyakarta: PP Nasyiatul Aisyiyah, 1968.

----, Materi Pendidikan Politik Bagi Perempuan Pemilih,Yogyakarta: PP Nasyiatul Aisyiyah, 1999.

----, Pedoman Umum Program Dakwah Terpadu Nasyiatul Aisyiyah, Yogyakarta: PP Nasyiatul Aisyiyah, 1998.

----, Sistem Perkaderan Nasyiatul Aisyiyah, Yogyakarta: PP Nasyiatul Aisyiyah, 2003. 
Puar, Yusuf Abdullah, Perjuangan dan Pengabdian Mubammadiyah, Jakarta: Pustaka Antara, 1989.

Rahman, Fazlur, Islam and Modernity: Transformation of an Intellectual Tradition, Chicago and London: The University of Chicago Press. Ramage, Douglas, Politics in Indonesia: Democracy, Islam and the Ideology of Tolerance, London and New York: Routledge 1995.

Robinson, Kathryn, "Gender, Islam and Culture in Indonesia" in Love, Sex and Power in Southeast Asia, edited by Susan Blackburn, Melbourne: Monash University Press, 2001.

----, "Indonesian Women from Orde Baru to Reformasi" in Women in Asia: Tradition, Modernity and Globalisation, edited by L. Edwards and M. Roces, St Leonard: Allen and Unwin, 2000.

Samson, Allan, "Army and Islam in Indonesia" in Pacific Affairs XLIX No. 4 (Winter 1971-1972); "Indonesian Islam since the New Order" in Readings on Islam in Southeast Asia, edited by A. Ibrahim, S. Siddique and Y. Husain, Singapore: Institute of Souetheast Asian Studies, 1985.

Setiawati, Nur Aini, "Sejarah Nasyiatul Aisyiyah di Kauman 19191965 " a thesis submitted to Gadjah Mada University, Indonesia, 1985.

Soebadio, Haryati and Saparinah Sadli, Kartini Pribadi Mandiri, Jakarta: Gramedia, 1990.

Suryakusuma, Julia, "Kultur Politik Kekerasan" in Politik Kekerasan ORBA: Akankah Terus Berlanjut, edited by S.A. Karim, Bandung: Mizan, 1999.

----, "State Ibuism: The Social Construction of Womanhood in the Indonesian New Order" in New Asian Vision 16 (1991) No 2.

----, "The State and Sexuality in New Order Indonesia" in Fantasizing the Feminine in Indonesia, edited by L.J. Sears, Durham and London: Duke University Press, 1996.

Suryochondro, Sukanti, Potret Pergerakan Wanita Indonesia,Jakarta: Rajawali, 1984. 
Syamsiyatun, Siti, "A Daughter in the Indonesian Muhammadiyah: Nasyiatul Aisyiyah Negotiates Its New Status and Image" in Oxford Journal of Islamic Studies 18:1 (2007).

Syamsuddin, Dien M., "Religion and Politics in Islam: the Case of Muhammadiyah in Indonesia's New Order", dissertation submitted to the University of California Los Angeles, 1991.

Umar, Nasaruddin, Argumen Kesetaraan Gender: Perspektif Al-Qur'an, Jakarta: Paramadina, 1999.

----, Kodrat Perempuan dalam Islam, Jakarta: Lembaga Kajian Agama dan Jender, 1999.

Vreede-De Stuers, Cora, The Indonesian Women: Struggles and Achievements, The Hague: Mouton, 1960.

Wadud, Amina, Qur'an and Women: Rereading the Sacred Text from a Women's Perspectives, New York: Oxford University Press, 1999.

Wieringa, Saskia, Women's Struggles and Strategies, Aldershot EnglandBrookfield, USA: Gower, 1988.

----, Penghancuran Gerakan Perempuan di Indonesia (The Politization of Gender Relations in Indonesia. Women's Movement and Gerwani until the New Order State). Translated by Hersri Setiawan, Jakarta: Garba Budaya dan Kalyanamitra, 1999.

Wolf, Diane, Factory Daughters: Gender, Household Dynamics and Rural Industrialization in Java, Berkeley: University of California Press, 1992. 